\title{
SEED PERFORMANCE AFTER EXPOSURE TO HIGH TEMPERATURES
}

\author{
W.R. SILVA \\ Depto. de Agricultura-ESALQ/USP, C.P. 9, CEP: 13418-900 - Piracicaba, SP, Brasil.
}

\begin{abstract}
In orthodox seed management, the application of temperatures over $42^{\circ} \mathrm{C}$ is routinely associated with deterioration while biological behaviors in operations conducted under high temperatures are hardly ever studied. The results found, however, indicate the possibility of stationary drying of soybean seeds at $50^{\circ} \mathrm{C}$, provided that the insufflated air flow intensity is considered, as well as the reduction of $B$. brizantha seed dormancy submitted to $85^{\circ} \mathrm{C}$.
\end{abstract}

Key Words: soybean, B. brizantha, seeds, use of heat

\section{DESEMPENHO DE SEMENTES APÓS EXPOSIÇÃO A ALTAS TEMPERATURAS}

RESUMO: No manejo de sementes ortodoxas, a aplicação de temperaturas superiores a $42^{\circ} \mathrm{C}$ é, rotineiramente, associada à deterioração e raramente são estudados os comportamentos biológicos presentes em operações conduzidas sob temperaturas superiores. Resultados obtidos, contudo, indicam possibilidades de secagem estacionária de sementes de soja a $50^{\circ} \mathrm{C}$, desde que considerada a intensidade do fluxo do ar insuflado, e de redução na dormência de sementes de $B$. brizantha submetidas a $85^{\circ} \mathrm{C}$. Descritores: soja, $B$. brizantha, sementes, uso do calor

\section{INTRODUCTION}

The environmental heat, an essential component to life, is an energy likely to be controlled for technological purposes. The recognition of its action on living beings has been physiologically studied and limits have been established for use in productive processes.

In the case of orthodox seed management the use of temperatures over $42^{\circ} \mathrm{C}$ is routinely associated with deterioration. Such generic scientific verification has interfered with research methods so that the biological behaviors resulting from the application of higher temperatures in specific cases as, for instance, drying and dormancy overcoming, are seldom studied.

\section{DRYING}

In view of the operational and economic facilities, the heat has been the means most employed promoting seed drying in history. Performing such operation demands compatible operational procedures regarding the physical yielding of water extraction and those related to the physiological preservation of seeds. However, doubts regarding the actions to be adopted to achieve best efficiency results in the process remain due to the variability of methods, equipment, environments, and plant species.

The stationary drying in silos with radial distribution of air is processed from center outwards; it occurs in layers according to the formation of drying zones corresponding to the water and heat exchange regions between the seed and the air. From the central tube of air distribution up to the drying front there are dry seeds and the temperature is similar to that of the insufflated air; farther to that front, moist seeds and lower temperature occur (Welch, 1967; Peske \& Baudet, 1980; Cavariani \& Baudet, 1982).

The air flow must be enough not to become saturated before leaving the seed mass (Brandenburg et al., 1961) and, accordingly, must be capable of absorbing all the water being released by the mass. In that situation, moving the water from the inner to the outer seed becomes the main factor to influence the drying time. McLean (1980) pondered that in dryers with radial distribution of air the scanty thickness in association with favorable aerodynamic characteristics lead the static pressure to be reduced and allow the use of air flows ranging $30 \mathrm{~m}^{3} / \mathrm{min} / \mathrm{t}$. 
Brooker et al. (1974) emphasized that drying temperatures must have as a reference that of the seed mass; thus, values ranging $40.5-43.3^{\circ} \mathrm{C}$ are considered maximum, above which injuries are likely to occur. Brandenburg et al. (1961) pointed that drying can, at first, be conducted under high air temperature, once the evaporation process removes heat enough not to change the temperature of seeds. On the other hand, Harrington (1972) revealed that since moist seeds are most susceptible to thermal injuries, the higher is the water content the lesser should be the temperature employed.

The primary cause of injuries produced in plant tissues by high temperatures is, according to Daniell et al. (1969), the disintegration of cell membranes, possibly by constituent lipid changes. Also accepted is the theory in which excessive heat provokes the denaturation of proteins. According to Herter \& Burris (1989a), thermal seed injuries are characterized by bursting peptidic links of proteins and in other cell components, and the beginning of the deleterious effect during high-temperature drying has been verified to possibly coincide with the beginning of embryo drying. The physiological injuries caused by drying can reflect on changes in subcellular systems including chromosomes (Roberts, 1972b; 1981) and mitochondria (Madden, 1992), in the reduction of the number of starch grains at the embryo axis, in increased electrolyte and sugar leaching and production of carotenoid pigments (Seyedin et al., 1984), and in reductions of cell membrane permeability (Seyedin et al., 1984; Herter \& Burris, 1989b) and respiratory rate (Madden, 1992).

A study focusing the understanding of joint actions of air flow $\left(26.9,28.4\right.$ and $\left.33.2 \mathrm{~m}^{3} / \mathrm{min} / \mathrm{t}\right)$ and temperature $\left(42,46\right.$ and $\left.50^{\circ} \mathrm{C}\right)$ in soybean seed drying in a stationary silo with radial distribution of insufflated air (Figures 1.a and 1.b) provided the following information (Miranda, 1997).
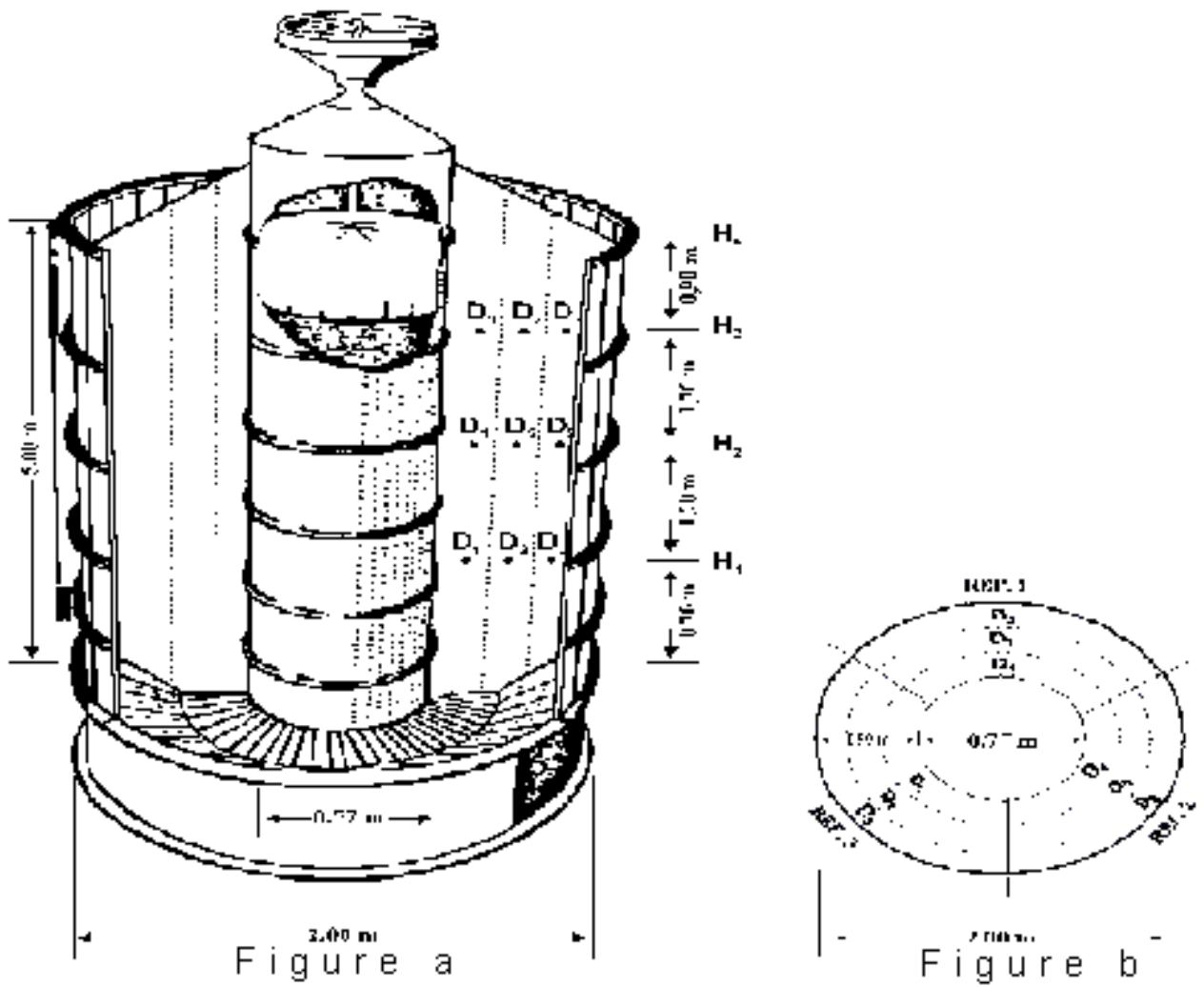

Figure 1 - Scheme of longitudinal (a) and transversal (a) sections of stationary dryer, brand ROTA, model RC 10, indicating the sampling distances $\left(\mathrm{D}_{1}, \mathrm{D}_{2}, \mathrm{D}_{3}\right)$ in heights $\mathrm{H}_{1}, \mathrm{H}_{2}, \mathrm{H}_{3}$ (Miranda, 1997). 


\section{PHYSICAL MONITORING}

(TABLE 1)

The maximum pressure (40 mm c.a.) found for static pressure confirm the possibility predicted by McLean (1980) of using high flows for the insufflated air in radial distribution dryers.

The mass temperature data were verified to decrease as the distance from seeds to the air insuf- flation cylinder was increased. In general, the stabilization of the mass temperature tended to be delayed as distance was increased, and the maximum figures reached along drying were invariably lower than those of the insufflated air temperature.

The drying speed data indicated that the combination between flow and intermediary temperature $\left(18,4 \mathrm{~m}^{3} / \mathrm{min} / \mathrm{t}\right.$ and $\left.46^{\circ} \mathrm{C}\right)$ was the fastest at water removal, regardless of the distance considered.

TABLE 1 - Mean data on insufflated air and soybean seed mass found during stationary drying conducted with the variation of temperature and flow of insufflated (Miranda, 1997).

\begin{tabular}{|c|c|c|c|c|c|c|c|}
\hline \multicolumn{4}{|c|}{ Insufflated air } & \multirow{2}{*}{$\begin{array}{l}\text { Seed mass } \\
\text { Dehidration }\left(\% \mathrm{H}_{2} \mathrm{O} / \mathrm{h}\right)\end{array}$} & \multicolumn{3}{|c|}{$\begin{array}{l}\text { Seed mass }\left(\mathrm{t}^{\circ} \mathrm{C}\right) \\
\text { Distances }(\mathrm{cm}) \text { in relation } \\
\text { to insufflation }\end{array}$} \\
\hline $\mathrm{T}^{\circ} \mathrm{C}$ & Flow $\left(\mathrm{m}^{3} / \mathrm{min} / \mathrm{t}\right)$ & $\mathrm{PV}(\mathrm{kPa})$ & $\mathrm{PE}$ (mm ca) & & $17\left(D_{1}\right)$ & $34\left(D_{2}\right)$ & $51\left(\mathrm{D}_{3}\right)$ \\
\hline \multirow{3}{*}{42} & 26.9 & 21.0 & 30.0 & 0.41 & 37.6 & 31.1 & 26.4 \\
\hline & 28.4 & 18.5 & 30.0 & 0.48 & 38.7 & 33.3 & 27.9 \\
\hline & 33.2 & 21.0 & 40.0 & 0.52 & 39.6 & 35.7 & 31.0 \\
\hline \multirow{3}{*}{46} & 26.9 & 23.5 & 30.0 & 0.49 & 42.8 & 37.3 & 31.9 \\
\hline & 28.4 & 15.1 & 30.0 & 0.87 & 41.0 & 32.0 & 27.0 \\
\hline & 33.2 & 25.3 & 40.0 & 0.52 & 41.6 & 38.1 & 33.8 \\
\hline \multirow[t]{3}{*}{50} & 26.9 & 22.5 & 30.0 & 0.44 & 47.0 & 39.9 & 33.4 \\
\hline & 28.4 & 18.8 & 30.0 & 0.56 & 45.3 & 38.1 & 31.0 \\
\hline & 33.2 & 23.0 & 40.0 & 0.58 & 44.3 & 39.6 & 34.7 \\
\hline
\end{tabular}

PE: Static pressure

PV: Steam pressure

\section{EVALUATION OF SEED QUALITY (TABLES 2 AND 3)}

The effects of drying on the physiological behavior of seeds through germination tests, electrical conductivity, tetrazolium (viability and vigor), accelerated aging, emergence and length of root and seedling were studied in two storage periods ( 0 through 6 months).

When individually analyzed, the tests indicated interactive actions of flows and temperatures with scarcely consistent tendencies. For that reason, in order to facilitate data interpretation, the interactions were studied considering the number and frequency of the statistical superiorities found along the pooled tests.

When temperature was set at $50^{\circ} \mathrm{C}$ the flows of 26.9 and $28.4 \mathrm{~m}^{3} / \mathrm{min} / \mathrm{t}$ overcame that of $33.2 \mathrm{~m}^{3} / \mathrm{min} / \mathrm{t}$ in $87.5 \%$ and $93.75 \%$ of cases, respectively. In the remaining temperatures, the frequencies of the superiorities were lower than $50 \%$, thus, there were no evident differences among flow effects on seed quality.

When the flow was set at $33.2 \mathrm{~m} / \mathrm{min} / \mathrm{t}$, temperatures of 42 and $46^{\circ} \mathrm{C}$ overcame $50^{\circ} \mathrm{C}$ in $87.5 \%$ and $81.25 \%$ of cases, respectively. In the other flows the superiority frequencies were lower than $50 \%$, thus not pointing differences among the temperature interference on seed performance.

Therefore, the associated use of lower flows (26.9 and $28.4 \mathrm{~m}^{3} / \mathrm{min} / \mathrm{t}$ ) with the highest temperature $\left(50^{\circ} \mathrm{C}\right)$ and lower temperatures $(42$ and $\left.46^{\circ} \mathrm{C}\right)$ with the highest flow $\left(33.2 \mathrm{~m}^{3} / \mathrm{min} / \mathrm{t}\right)$ lessened the deterioration resulting from drying; also, positive effects of flow raising were indicated to arise from lower temperature and vice versa. 
TABLE 2 - Occurrence ( $n^{\circ}$ and frequency) of superiority with statistical support verified in evaluation tests of physiological quality, with temperatures set at the interactions between flow and temperature of insufflated air (Miranda, 1997).

\begin{tabular}{|c|c|c|c|c|c|}
\hline \multirow{2}{*}{$\begin{array}{l}\text { Fixed Cause } \\
\text { (temperature) }\end{array}$} & \multirow[b]{2}{*}{ Superiority } & \multicolumn{3}{|c|}{ Occurrence $\left(\mathrm{n}^{\circ}\right)$ during storage } & \multirow{2}{*}{$\begin{array}{l}\text { Frequency }(\%) \text { of occurrence } \\
\text { in the total of } 16 \text { possible ones } \\
\text { ( } 8 \text { tests } \times 2 \text { periods) }\end{array}$} \\
\hline & & 0 month & 6 months & Sum & \\
\hline \multirow[t]{6}{*}{$42^{\circ} \mathrm{C}$} & $26.9>>28.4 \mathrm{~m}^{3} / \mathrm{min} / \mathrm{t}$ & 2 & 1 & 3 & 18.75 \\
\hline & $26.9>>33.2 \mathrm{~m} 3 / \mathrm{min} / \mathrm{t}$ & 2 & 1 & 3 & 18.75 \\
\hline & $28.4>>26.9 \mathrm{~m}^{3} / \mathrm{min} / \mathrm{t}$ & 0 & 3 & 3 & 18.75 \\
\hline & $28.4>>33.2 \mathrm{~m}^{3} / \mathrm{min} / \mathrm{t}$ & 0 & 1 & 1 & 6.25 \\
\hline & $33.2>>26.9 \mathrm{~m}^{3} / \mathrm{min} / \mathrm{t}$ & 3 & 3 & 6 & 37.50 \\
\hline & $33.2 \gg>28.4 \mathrm{~m}^{3} / \mathrm{min} / \mathrm{t}$ & 2 & 1 & 3 & 18.75 \\
\hline \multirow[t]{6}{*}{$46{ }^{\circ} \mathrm{C}$} & $26.9>>28.4 \mathrm{~m}^{3} / \mathrm{min} / \mathrm{t}$ & 3 & 3 & 6 & 37.50 \\
\hline & $26.9>>33.2 \mathrm{~m}^{3} / \mathrm{min} / \mathrm{t}$ & 2 & 3 & 5 & 31.25 \\
\hline & $28.4>>26.9 \mathrm{~m}^{3} / \mathrm{min} / \mathrm{t}$ & 2 & 0 & 2 & 12.50 \\
\hline & $28.4>>33.2 \mathrm{~m}^{3} / \mathrm{min} / \mathrm{t}$ & 2 & 2 & 4 & 25.00 \\
\hline & $33.2>>26.9 \mathrm{~m}^{3} / \mathrm{min} / \mathrm{t}$ & 2 & 1 & 3 & 18.75 \\
\hline & $33.2>>28.4 \mathrm{~m}^{3} / \mathrm{min} / \mathrm{t}$ & 4 & 3 & 7 & 43.75 \\
\hline \multirow[t]{6}{*}{$50{ }^{\circ} \mathrm{C}$} & $26.9>>28.4 \mathrm{~m}^{3} / \mathrm{min} / \mathrm{t}$ & 2 & 2 & 4 & 25.00 \\
\hline & $26.9>>33.2 \mathrm{~m}^{3} / \mathrm{min} / \mathrm{t}$ & 6 & 8 & 14 & 87.50 \\
\hline & $28.4>>26.9 \mathrm{~m}^{3} / \mathrm{min} / \mathrm{t}$ & 2 & 0 & 2 & 12.50 \\
\hline & $28.4>>33.2 \mathrm{~m}^{3} / \mathrm{min} / \mathrm{t}$ & 8 & 7 & 15 & 93.75 \\
\hline & $33.2>>26.9 \mathrm{~m}^{3} / \mathrm{min} / \mathrm{t}$ & 2 & 0 & 2 & 12.50 \\
\hline & $33.2>>28.4 \mathrm{~m}^{3} / \mathrm{min} / \mathrm{t}$ & 0 & 0 & 0 & 0.00 \\
\hline
\end{tabular}

TABLE 3 - Occurrence ( $\mathrm{n}^{\circ}$ and frequency) of superiority with statistical support verified in evaluation tests of physiological quality, with flows set at the interactions between flow and temperature of insufflated air (Miranda, 1997).

\begin{tabular}{|c|c|c|c|c|c|}
\hline \multirow{2}{*}{$\begin{array}{l}\text { Fixed Cause } \\
\text { (flow) }\end{array}$} & \multirow[b]{2}{*}{ Superiority } & \multicolumn{3}{|c|}{ Occurrence $\left(\mathrm{n}^{\circ}\right)$ during storage } & \multirow{2}{*}{$\begin{array}{l}\text { Frequency }(\%) \text { of occurrence } \\
\text { in the total of } 16 \text { possible ones } \\
\text { ( } 8 \text { tests } \times 2 \text { periods) }\end{array}$} \\
\hline & & 0 month & 6 months & Sum & \\
\hline \multirow[t]{6}{*}{$26.9 \mathrm{~m}^{3} / \mathrm{min} / \mathrm{t}$} & $42{ }^{\circ} \mathrm{C}>>46{ }^{\circ} \mathrm{C}$ & 2 & 0 & 2 & 12.50 \\
\hline & $42{ }^{\circ} \mathrm{C}>>50{ }^{\circ} \mathrm{C}$ & 2 & 2 & 4 & 25.00 \\
\hline & $46{ }^{\circ} \mathrm{C}>>42{ }^{\circ} \mathrm{C}$ & 3 & 2 & 5 & 31.25 \\
\hline & $46{ }^{\circ} \mathrm{C}>>50{ }^{\circ} \mathrm{C}$ & 2 & 2 & 4 & 25.00 \\
\hline & $50{ }^{\circ} \mathrm{C}>>42^{\circ} \mathrm{C}$ & 2 & 4 & 6 & 37.50 \\
\hline & $50{ }^{\circ} \mathrm{C}>>46^{\circ} \mathrm{C}$ & 0 & 1 & 1 & 6.25 \\
\hline \multirow[t]{6}{*}{$28.4 \mathrm{~m}^{3} / \mathrm{min} / \mathrm{t}$} & $42{ }^{\circ} \mathrm{C}>>46{ }^{\circ} \mathrm{C}$ & 2 & 4 & 6 & 37.50 \\
\hline & $42{ }^{\circ} \mathrm{C}>>50{ }^{\circ} \mathrm{C}$ & 0 & 1 & 1 & 6.25 \\
\hline & $46{ }^{\circ} \mathrm{C}>>42{ }^{\circ} \mathrm{C}$ & 2 & 0 & 2 & 12.50 \\
\hline & $46{ }^{\circ} \mathrm{C}>>50{ }^{\circ} \mathrm{C}$ & 1 & 1 & 2 & 12.50 \\
\hline & $50{ }^{\circ} \mathrm{C}>>42{ }^{\circ} \mathrm{C}$ & 2 & 0 & 2 & 12.50 \\
\hline & $50{ }^{\circ} \mathrm{C}>>46{ }^{\circ} \mathrm{C}$ & 4 & 2 & 6 & 37.50 \\
\hline \multirow[t]{6}{*}{$33.2 \mathrm{~m} / 3 / \mathrm{min} / \mathrm{t}$} & $42{ }^{\circ} \mathrm{C}>>46{ }^{\circ} \mathrm{C}$ & 0 & 3 & 3 & 16.75 \\
\hline & $42{ }^{\circ} \mathrm{C}>>50{ }^{\circ} \mathrm{C}$ & 6 & 8 & 14 & 87.50 \\
\hline & $46{ }^{\circ} \mathrm{C}>>42{ }^{\circ} \mathrm{C}$ & 0 & 1 & 1 & 6.25 \\
\hline & $46{ }^{\circ} \mathrm{C}>>50{ }^{\circ} \mathrm{C}$ & 6 & 7 & 13 & 81.25 \\
\hline & $50{ }^{\circ} \mathrm{C}>>42{ }^{\circ} \mathrm{C}$ & 2 & 0 & 2 & 12.50 \\
\hline & $50{ }^{\circ} \mathrm{C}>>46^{\circ} \mathrm{C}$ & 2 & 0 & 2 & 12.50 \\
\hline
\end{tabular}




\section{CONCLUSIONS}

Drying speed data indicated operational physical advantages to the situation in which temperature and intermediary flows were applied $\left(46^{\circ} \mathrm{C}\right.$ and $\left.28.4 \mathrm{~m}^{3} / \mathrm{min} / \mathrm{t}\right)$ onto the insufflated air. On the other hand, regarding the management of the physiological quality maintenance, the results highlighted that the increase of temperature demands flow reduction and, conversely, the increase of the flow demands temperature reduction. Thus, the importance of the consideration of the joint action of flow and temperature in studies on that subject stand out.

\section{DORMANCY OVERCOMING}

The production of tropical foraging grass seeds, in addition to uneven maturation and degranulation, usually shows dormancy of seeds whose nature, intensity, and persistence have not yet been thoroughly studied. Such physiological phenomenon hinders an even establishment of populations and also favors the arise of invading plants in pasture. The study of alternatives to overcome dormancy can be of help in the evaluation of the physiological quality in laboratory and, specially, to contribute for the development of methods that, in a large scale, would allow the commercialization of seeds with partial or totally eliminated dormancy.

Roberts (1972a) acredited the dormancy of foraging grass seeds specially to the presence of oxygen-fixing substances onto covering structures. Likewise, Renard \& Capele (1976) stated that the low germination of Brachiaria ruziziensis seeds resulting from dormancy can be attributed to the oxygen diffusion restriction and to the hindrance imposed by the glumes.

Bewley \& Black (1982) considered that the hormones promoting germination, particularly gibberellin and cytokinin, interacted with inhibitors so as to allow germination. Khan (1970) proposed the existence of a promoter-inhibitor balance in which the quantitative relation of regulating substances would determine the control of dormancy; in addition, he emphasized that the lemma and the palea would be structures accountable for the imposition of dormancy in grass seeds. Maeda (1995), while evaluating the effect of the lemma and the palea on Paspalum notatum seeds verified that the lemma alone did not interfered with the germination while the withdrawal of the palea resulted in an increase of $80 \%$ in the results.

Among the treatments known to overcome dormancy, the chemical scarification with sulfuric acid has been applied in lots with commercialization purposes. The method, however, presents operational risks to workers, pollutes the environment, in addition to promoting qualitative injuries to seeds.

Thermal treatments using temperatures considered potentially harmful to the physiological quality of seeds have been applied in researches viewing dormancy overcoming.

Preheating at $40^{\circ} \mathrm{C}$, as indicated to overcome seed dormancy in several grass species (ISTA, 1985) has been recommended for $B$. brizanth $a$ and $B$. ramosa (Brazil, 1992). Hodgson (1949) verified, in Paspalum notatum, that seed preheating for four days at 27 , 47,57 , and $67^{\circ} \mathrm{C}$ increased germination in relation to the exposure for two days. Hopkinson et al. (1988), however, reported that the dormancy in Paspalum notatum apparently is not affected by seed preheating. Mastrocola et al. (1980) verified that predrying and sulfuric acid application treatments in green panic (Panicum maximum) seeds decreased the germination in relation to that of the control. Butler (1985), on the other hand, found the promotion of germination in buffel grass (Cenchrus ciliaris) seeds with preheating at $40^{\circ} \mathrm{C}$ for 10 days.

Lago (1974), while studying the effects of preheating at $40^{\circ} \mathrm{C}$, tip cut, chemical scarification, and substrate imbibition with $\mathrm{KNO}_{3}$ in freshly harvested Brachiaria brizantha seeds concluded that the use of preheating and chemical scarification followed by the application of $\mathrm{KNO}_{3}$ onto the substrate were most efficient.

The use of accelerated aging involving temperatures close to $42^{\circ} \mathrm{C}$ resulted in dormancy overcoming in Brachiaria brizantha seeds (Pires, 1993; Martins, 1995; Pires, 1997).

Maeda (1995) observed that the treatment at $40^{\circ} \mathrm{C}$ in a nonhermetic packaging turned out to be a method for overcoming the dormancy of P. notatum seeds possibly due to the neutralizing effects, or concentration decrease, of phenolic substances at the glumes and of production, or activation, of cytokinin detected at the base of the caryopses of untreated seeds. He stated that although the drying at $60^{\circ} \mathrm{C}$ may cause irreversible viability losses in several plant species seeds, the Paspalum notatum seeds did not go through physiological injuries when submitted to such situation. 
Phaneendranath (1977), in a study with Kentucky bluegrass (Poa pratensis L.) seeds verified that treatments with $50-60^{\circ} \mathrm{C}$ for as long as four days favored seed germination. Likewise, applications of 40 and $55^{\circ} \mathrm{C} / 15 \mathrm{~h}$ in seeds of Panicum maximum (Martins, 1996) and $80^{\circ} \mathrm{C} / 10 \mathrm{~h}$ in seeds of Brachiaria brizantha (Martins et al., 1997) led to dormancy overcoming.

Thus, considering the use of heat as a feasible technique for industrial use with reduced environmental impact, preliminary data were found with seeds of Brachiaria brizantha (Martins, 1998) submitted, among other treatments, to the action of heat $\left(40,55,70\right.$ and $85^{\circ} \mathrm{C}$ during 5,10 , and $15 \mathrm{~h}$ ).

\section{DORMANCY AND PHYSIOLOGICAL PERFORMANCE (TABLE 4)}

In both lots, treatments $\mathrm{GA}_{3}, 40^{\circ} \mathrm{C}, 55^{\circ} \mathrm{C}$, and $70^{\circ} \mathrm{C}$ showed no statistical differences regarding the control in most tests. This fact, although not pointing any advantages in the application of such treatments, suggests the absence of harmful physiological effects resulting from the action of heat at temperatures of up to $70^{\circ} \mathrm{C} / 15 \mathrm{~h}$.

On the other hand, the other treatments were effective in reducing the dormancy rate. Among these, those of $\mathrm{H}_{2} \mathrm{SO}_{4}$ and $85^{\circ} \mathrm{C} / 15 \mathrm{~h}$ (except in the germination of lot $\mathrm{B}$ ), and $85^{\circ} \mathrm{C} / 10 \mathrm{~h}$ (except in the

TABLE 4 - Mean data on germination (G), dormancy rate (D), first count of germination $\left(1^{\mathrm{a}} \mathrm{C}\right)$, and emergence (E) found with Brachiaria brizantha seeds submitted to different treatments (Martins, 1998 preliminary data).

\begin{tabular}{|c|c|c|c|c|c|c|c|c|}
\hline \multirow[b]{2}{*}{ Treatments } & \multicolumn{4}{|c|}{ Lot A } & \multicolumn{4}{|c|}{ Lot B } \\
\hline & $\mathrm{D}(\%)$ & $\mathrm{G}(\%)$ & $1^{\mathrm{a}} \mathrm{C}(\%)$ & $\mathrm{E}(\%)$ & $\mathrm{D}(\%)$ & $\mathrm{G}(\%)$ & $1^{\mathrm{a}} \mathrm{C}(\%)$ & $\mathrm{E}(\%)$ \\
\hline Control & $33 \mathrm{ab}$ & 61def & $35 \mathrm{cde}$ & $33 \mathrm{c}$ & $31 a b$ & 56defg & 30def & $38 \mathrm{~cd}$ \\
\hline $\mathrm{H}_{2} \mathrm{SO}_{4}$ & $0 \mathrm{~d}$ & 81abc & $68 \mathrm{a}$ & $73 a$ & 10de & $72 \mathrm{bcd}$ & $65 \mathrm{~b}$ & $78 \mathrm{a}$ \\
\hline $\mathrm{KNO}_{3}^{2}$ & $4 \mathrm{~cd}$ & $86 a b$ & $36 \mathrm{bcde}$ & - & $5 e$ & $70 \mathrm{bcde}$ & $44 \mathrm{~cd}$ & - \\
\hline $\mathrm{H}_{2} \mathrm{SO}_{4}^{3}+\mathrm{KNO}_{3}$ & $1 \mathrm{~d}$ & $87 \mathrm{a}$ & $57 \mathrm{abc}$ & - & $4 \mathrm{e}$ & $87 \mathrm{a}$ & $82 \mathrm{a}$ & - \\
\hline $\mathrm{GA}_{3}^{2}$ & $18 \mathrm{bc}$ & 69abcdef & $54 \mathrm{abcd}$ & - & $22 b c$ & 60defg & 28def & - \\
\hline $40^{\circ} \mathrm{C} / 5 \mathrm{~h}$ & $28 \mathrm{ab}$ & $64 \mathrm{cdef}$ & $26 \mathrm{e}$ & $30 \mathrm{c}$ & $32 \mathrm{ab}$ & 56defg & $23 \mathrm{f}$ & $53 \mathrm{bc}$ \\
\hline $40^{\circ} \mathrm{C} / 10 \mathrm{~h}$ & $42 a$ & $55 \mathrm{f}$ & 29de & $36 \mathrm{bc}$ & $33 a b$ & 52efg & $24 \mathrm{ef}$ & $37 \mathrm{~cd}$ \\
\hline $40^{\circ} \mathrm{C} / 15 \mathrm{~h}$ & $37 a b$ & $51 \mathrm{f}$ & $33 \mathrm{cde}$ & $32 \mathrm{c}$ & $28 \mathrm{ab}$ & 59defg & $32 \mathrm{def}$ & $40 \mathrm{~cd}$ \\
\hline $55^{\circ} \mathrm{C} / 5 \mathrm{~h}$ & $33 a b$ & $58 \mathrm{ef}$ & 30de & $35 b c$ & $36 \mathrm{a}$ & $51 \mathrm{fg}$ & $22 \mathrm{f}$ & $33 d$ \\
\hline $55^{\circ} \mathrm{C} / 10 \mathrm{~h}$ & $33 a b$ & $58 \mathrm{ef}$ & $32 \mathrm{cde}$ & $36 \mathrm{bc}$ & $35 \mathrm{ab}$ & 54efg & $24 \mathrm{ef}$ & $37 \mathrm{~cd}$ \\
\hline $55^{\circ} \mathrm{C} / 15 \mathrm{~h}$ & $30 \mathrm{ab}$ & $62 \mathrm{def}$ & 40bcde & $44 \mathrm{bc}$ & $26 a b c$ & 63defg & 28def & $54 \mathrm{bc}$ \\
\hline $70^{\circ} \mathrm{C} / 5 \mathrm{~h}$ & $23 a b$ & $63 \mathrm{cdef}$ & 37bcde & $37 \mathrm{bc}$ & $35 \mathrm{ab}$ & $49 \mathrm{~g}$ & $28 \mathrm{def}$ & $36 \mathrm{~cd}$ \\
\hline $70^{\circ} \mathrm{C} / 10 \mathrm{~h}$ & $27 \mathrm{ab}$ & $62 \mathrm{def}$ & $39 \mathrm{bcde}$ & $47 b c$ & $22 a b c$ & 66defg & 40de & $45 \mathrm{~cd}$ \\
\hline $70^{\circ} \mathrm{C} / 15 \mathrm{~h}$ & $22 \mathrm{ab}$ & $69 \mathrm{cdef}$ & 48abcde & $57 \mathrm{ab}$ & $22 a b c$ & $68 \mathrm{cdef}$ & $41 d$ & $53 \mathrm{bcd}$ \\
\hline $85^{\circ} \mathrm{C} / 5 \mathrm{~h}$ & $3 d$ & $89 a$ & $68 \mathrm{a}$ & $73 a$ & $15 \mathrm{~cd}$ & 70bcde & $60 \mathrm{bc}$ & $76 a$ \\
\hline $85^{\circ} \mathrm{C} / 10 \mathrm{~h}$ & $5 \mathrm{~cd}$ & $80 \mathrm{abcd}$ & 44abcde & $72 \mathrm{a}$ & $4 e$ & $83 a b c$ & $67 \mathrm{ab}$ & $74 \mathrm{a}$ \\
\hline $85^{\circ} \mathrm{C} / 15 \mathrm{~h}$ & $3 d$ & 75abcde & $63 \mathrm{ab}$ & $76 a$ & $5 e$ & $84 \mathrm{ab}$ & $73 \mathrm{ab}$ & $70 \mathrm{ab}$ \\
\hline
\end{tabular}

germination and first count of lot $\mathrm{A})$, and $85^{\circ} \mathrm{C} / 5 \mathrm{~h}$ (except in the germination of lot $\mathrm{B}$ ) promoted increases in the physiological performance of most tests. The use of $\mathrm{KNO}_{3}$ although efficient in decreasing the dormancy rate, overcame the control exclusively in the germination of lot A.; when associated to the $\mathrm{H}_{2} \mathrm{SO}_{4}$, however, the treatment failed to overcome the control only at the first count test of lot A.

\section{CONCLUSIONS}

Considering the treatments with application possibilities during industrial seed processing, the use of $\mathrm{H}_{2} \mathrm{SO}_{4}$ and $85^{\circ} \mathrm{C} / 5$ at $15 \mathrm{~h}$ was beneficial to overcome the dormancy in Brachiaria brizantha seeds. However, when environmental pollution and work safety features are considered, the inconveniences regarding the use of $\mathrm{H}_{2} \mathrm{SO}_{4}$ must be emphasized. 


\section{REFERENCES}

BEWLEY, J.D.; BLACK, M. Physiology and biochemistry of seeds in relation to germination: viability, dormancy and environmental control. Berlin: Springer-Verlag, 1982. v.2, 375p.

BRANDENBURG, N.R.; SIMONS, J.W.; SMITH, L.L. Why and how seeds are dried. Yearbook of Agriculture-1961 offprint,1961. p.295-306.

BRASIL. Ministério da Agricultura. Regras para análise de sementes. Brasília: SNDA/DNFV/CLV, 1992a. 365p.

BROOKER, D.B.; BAKKER-ARKEMA, F.W.; HALL, C.W. Drying cereal grains. Westport: AVI, 1974. $265 \mathrm{p}$.

BUTLER, J. E. Germination of Buffel grass (Cenchrus ciliares). Seed Science and Technology, v.13, p.583-591, 1985 .

CAVARIANI, C.; BAUDET, L.M.L. Secagem de sementes. Informe Agropecuário, v.8, n.91, p.44-49, 1982.

DANIELL, J.W.; CHAPPELL, W.E.; COUCH, H.B. Effect of sublethal and lethal temperatures on plant cells. Plant Physiology, v.44, p.1684-1689, 1969.

HARRINGTON, J.F. Seed storage and longevity. In: KOZLOWSKI, T.T. Seed biology. New York: Academic Press, 1972. v.3, p.145-245.

HERTER, U.; BURRIS, J.S. Changes in moisture, temperature, and quality of corn seed during hightemperature drying. Canadian Journal of Plant Science, v.69, n.3, p.749-761, 1989a.

HERTER, U.; BURRIS, J.S. Evaluating drying injury on corn seed with a conductivity test. Seed Science and Technology, v.17, p.625-638, 1989b.

HODGSON, H.J. Effect of heat and acid scarification on the germination of seed of Bahiagrass, Paspalum notatum. Agronomy Journal, v.41, n.11, p.531-533, 1949.

HOPKINSON, J.M.; ENGLISH, B.H.; HARTY, R.L. Effects of different drying patterns on quality of seed of some tropical pasture grasses. Seed Science and Technology, v.16, n.2, p.361-369, 1988.

INTERNATIONAL SEED TESTING ASSOCIATION (ISTA). International rules for seed testing 1985. Seed Science and Technology, v.13, n.2, p. 299-355, 1985.
KHAN, A.A. ABA and kinetin induced changes in cell homogenates, chromatin - bound RNA polymerase and RNA composition. In: CARR, D.J. (Ed.) Plant growth substances. New York: Springer-Verlag, 1970. p.207-215.

LAGO, A.A. Observações sobre germinação de Brachiaria brizantha. Semente, Brasília, n.0, p.34-37, 1974.

MADDEN, R.F. Early germination physiology in hybrid maize (Zea mays L.) embryos damaged by hightemperature desiccation. Dissertation Abstracts International, Series B, v.52, n.11, p.5614, 1992.

MAEDA, J.A. Aspectos físicos e fisiológicos na germinação e dormência de sementes de gramabatatais (Paspalum notatum Flügge). Campinas, 1995. 141p. Tese (Doutorado) - Instituto de Biologia, Universidade Estadual de Campinas.

MARTINS, C. Superação da dormência em sementes de Panicum maximum Jacq.: seleção de métodos para aplicação em escala industrial. Piracicaba, 1996. 63p. Tese (Doutorado) - Escola Superior de Agricultura "Luiz de Queiroz", Universidade de São Paulo.

MARTINS, L. Avaliação da qualidade fisiológica de sementes de Brachiaria brizantha durante o armazenamento. Campinas, 1995. 72p. Dissertação (Mestrado) - Faculdade de Engenharia Agrícola, Universidade de Campinas.

MARTINS, L. Dormência em sementes de Brachiaria brizantha 1998. (unpublished preliminary data)

MARTINS, L.; SILVA, W.R.; LOT, R.C.; MALAVOLTA, V.M. Tratamentos térmicos e superação da dormência em sementes de Brachiaria brizantha. Informativo Abrates, v.7, n.1/2, p.245, 1997.

MASTROCOLA, M.A; OLIVEIRA, P.R.; ALCÂNTARA, P.B. Efeito de tratamentos físicos e químicos na viabilidade de sementes de green panic (Panicum maximum var. trichoglume cv. Petrie). Zootecnia, v.18, n.2, p.103-108, jun. 1980.

McLEAN, K.A. Drying and combinable crops. Ipswich: Farming, 1980. 280p.

MIRANDA, L.C. Secagem de sementes de soja em silo com distribuição radial do fluxo de ar. Piracicaba, 1997. 76p. Tese (Doutorado) - Escola Superior de Agricultura "Luiz de Queiroz", Universidade de São Paulo. 
PESKE, S.T.; BAUDET, L.M. Considerações sobre secagem de sementes. Viçosa: CENTREINAR, 1980. 19p.

PHANEENDRANATH, B.R. Effects of accelerated aging and dry heat treatments on dormancy and viability of freshly harvested Kentucky bluegrass seed. Journal of Seed Technology, v.2, n.1, p.11-17. 1977

PIRES, J.C. Efeito do envelhecimento precoce sobre a dormência de sementes de Brachiaria brizantha. Botucatu, 1997. 71p. Tese (Doutorado) - Faculdade de Ciências Agronômicas, Universidade Estadual Paulista.

PIRES, J.C. Superação da dormência através do envelhecimento precoce em sementes de Brachiaria brizantha. Botucatu, 1993. 88p. Dissertação (Mestrado) - Faculdade de Ciências Agronômicas, Universidade Estadual Paulista.

RENARD, C. ; CAPELLE, P. Seed germination in Ruzizi grass (Brachiaria ruziziensis Germain \& Everard). Australian Journal of Botany, v.24, n.4, p.437-446, 1976.
ROBERTS, E.H. Oxidative processes and the control of seed germination. In: HEYDECKER, W. (Ed.). Seed Ecology. London: Butterworths, 1972a. p. 189-218.

ROBERTS, E.H. Storage environment and the control of viability. In: ROBERTS, E.H. (Ed.) Viability of seeds. Syracuse: Syracuse University Press, 1972b. cap.2, p.14-58.

ROBERTS, E.H. Physiology of ageing and its application to drying and storage. Seed Science and Technology, v.9, p.379-372, 1981.

SEYEDIN, N.; BURRIS, J.S.; FLYNN, T.E. Physiological studies on the effects of drying temperatures on corn seed quality. Canadian Journal of Plant Science, v.64, p.497-504, 1984.

WELCH, J.B. Articles on seed drying. Seedmen's Digest offprint, 1967. p.1-15

Recebido para publicação em 10/07/98 Aceito para publicação em 03/08/98 